\title{
Exchange Rate Movement and Foreign Direct Investment in Asean Economies
}

\author{
Jaratin Lily, Mori Kogid, Dullah Mulok, Lim Thien Sang, and Rozilee Asid \\ School of Business and Economics, Universiti Malaysia Sabah, Jalan UMS, 88400 Kota Kinabalu, Sabah, Malaysia
}

Correspondence should be addressed to Mori Kogid; morikogid@gmail.com

Received 29 November 2013; Revised 24 February 2014; Accepted 2 March 2014; Published 30 March 2014

Academic Editor: Junsoo Lee

Copyright (C) 2014 Jaratin Lily et al. This is an open access article distributed under the Creative Commons Attribution License, which permits unrestricted use, distribution, and reproduction in any medium, provided the original work is properly cited.

The inflows of foreign direct investment (FDI) are important for a country's economic development, but the world market for FDI has become more competitive. This paper empirically analyses the exchange rate movements and foreign direct investment (FDI) relationship using annual data on ASEAN economies, that is, Malaysia, the Philippines, Thailand, and Singapore. By employing ARDL bounds test approach, the empirical results show the existence of significant long-run cointegration between exchange rate and FDI for the case of Singapore, Malaysia, and the Philippines with all countries recording negative coefficient implying that the appreciation of Singapore dollar, Malaysian ringgit, and the Philippine peso has a positive impact on FDI inflows. Using the ECM based ARDL approach for causality test, both Singapore and the Philippines show long-run bidirectional causality between exchange rate and FDI whereas long-run unidirectional causality running from the exchange rate to FDI in Malaysia. Furthermore, this study also found that short-run unidirectional causality running from the exchange rate to FDI exists in Singapore.

\section{Introduction}

Foreign direct investment (FDI) is an international flow of capital that provides a parent company or multinational enterprises (MNEs) with control over foreign affiliates. Since the early 1980s, FDI is increasingly recognised as an important instrument for resource to flow across national borders to improve economic performance, industrial and international competitiveness, and exports [1]. In a perfectly competitive economy, there would be no FDI but researchers now tend to use imperfect and asymmetric information of the market characteristics to explain FDI flows [2]. Given these significant roles of FDI, several studies have tried to determine the factors that influence FDI inflows into countries regardless of what the markets are (e.g., [3-8]). One of the factors that recently has been a source of debate is the exchange rate.

FDI theory based on exchange rate analyses the relationship of FDI flows and exchange rate changes. The existing literature has conflicting issues, with some studies supporting the significant relationship whilst others reject it. The direction of the relationship between FDI and exchange rate also varies with some findings showing a positive effect of exchange rate on FDI [9-14] and other findings suggesting a negative effect $[15,16]$. The objective of the FDI, cost reduction, and FDI as a tool for exchange rate risk are some of the explanations behind the issue.

In some studies, the relationship between the exchange rate and FDI can be from FDI to exchange rate [17-19]. This is not a surprising result because the inflows of FDI can also influence the appreciation or depreciation of the local exchange rate through the increased demand for home currency. Thus, the question of the significance and direction of the relationship between exchange rate and FDI are still intensely relevant until now.

Albuquerque et al. [20] argued that the significant importance of FDI in emerging markets is linked to an increased integration of world capital markets following the many reforms and liberalization programs in the 1980s. FDI has played a larger role in the ASEAN region, and this role has become more significant since the mid-1980s [21, 22]. Each of ASEAN countries has also provided investment incentives, which have indirectly increased competition among the ASEAN countries to attract FDI.

Even though most of the Southeast Asian countries adopt the managed floating exchange rate regime, MNEs may still 
have to face the exchange rate risk in these countries which may affect the MNEs investment value in the future due to the level of competitiveness among the countries through their level of foreign exchange rate. Therefore, the objective of this paper is to investigate the relationship between the foreign exchange rate movements and the foreign investment inflows among the selected ASEAN countries (Malaysia, the Philippines, Singapore, and Thailand).

Contrary to the existing empirical studies in ASEAN countries that examine the relationship between FDI and exchange rate, our study takes the issue of the real value of the exchange rate and FDI in our testing analysis seriously. Analysing the exchange rate at the real value is important in these countries because the managed floating exchange rate represents significant government intervention in managing the exchange rate at certain ranges $[23,24]$. Therefore, the real value of the exchange rate may show the true level of competitiveness of the country in the world market [25]. The current study applies the cointegration and causality analysis instead of standard regression analysis because the variables tested are not stationary at the level.

The structure of the paper is as follows: selected literature review of FDI and exchange rate relationships is discussed in the next section. Section 3 describes the data set and methodology; Section 4 presents the empirical results whilst Section 5 elaborates the discussion and conclusion.

\section{Literature Review}

A large number of studies have been conducted, which lead to identifying the determinants of FDI. However, there is no consensus accepting any set of explanatory variables that can be regarded as the correct determinants of FDI [2, 9, $26,27]$. Country effect, differences in perspectives, markets, methodologies, sample-selection, and analytical tools are the possible explanation for this mixed empirical evidence.

The relationship between FDI flows and exchange rate movements are based on the currency area of FDI theory with two different directions [2]. A financial view of FDI is conditional on some form of imperfections or information asymmetry in international financial markets where the exchange rate is one of the most important financial variables that affect the relative advantage of a MNE in comparison with a local firm [26]. A firm is assumed to maximize its profits given an exchange rate for a potential host country with respect to the FDI source country. Under this framework, depreciation of the host country currency is likely to attract FDI inflows at least for the following two reasons. Firstly, MNE has an advantage over a domestic firm because of its ability to obtain financing in international capital markets in strong-currency terms for lower cost due to its reputation [2]. Therefore, they can take higher profitable project because they can acquire higher value from the same project than the local firms due to lower cost of capital. Pursuant to that, countries with weak currencies tend to be recipients of FDI while countries with strong currencies tend to be sources of FDI. Secondly, the currency depreciation reduces production costs in the host country, thereby making it attractive for
FDI seeking production efficiency and revenues $[9,15]$. In other words, FDI can be a tool for foreign exchange risk hedging with the assumption that MNE may be more efficient in hedging the risk.

However, these effects and relationship direction between the exchange rate and FDI are still uncertain because the effect of the exchange rate on the FDI also depends on the destination of goods produced [15]. If the FDI's objective is to serve the host country market, then the FDI and trade are substitutes; in which case, the appreciation of the host currency attracts the FDI inflows due to higher purchasing power of the domestic consumers. On the other hand, if the FDI's objective is for reexport purpose, so the FDI and trade are complemented, in this case, appreciation of the host currency reduces the FDI inflows through lower competitiveness. Thus, the depreciation in the host country exchange rate will increase the FDI inflow since it reduces the cost of capital investment.

The empirical evidences of the relationship between exchange rate and FDI flows are mixed. Several studies, including Caves [15], Kogut and Chang [11], and Blonigen [9], indicated the significant relationship between dollar depreciations and enhanced FDI inflows to the United States. For instance, Caves [15] study showed a significant negative correlation between the level of the exchange rate (both nominal and real) and inflows of FDI in the US. Meanwhile, Froot and Stein [10] argued that the presence of the capital market imperfections motivate the firms to invest abroad if their home currency appreciates because of their increment in relative wealth and this will make external finance become more costly than internal finance. Therefore, the study revealed that a real depreciation of the US dollar increases the FDI inflow in the US for periods between 1973 and 1988. The relationship seemed to be more prominent in the industries with a higher level of potential information asymmetry such as chemical and machinery industries.

On the contrary, Stevens [28] study found weak empirical support and showed evidence of serious instability in the Froot and Stein [10] study hypothesis. The study findings showed that the significant relationship between the exchange rate and FDI inflows disappear for an important subperiod of the 1973-1988 periods and when the sample series were extended through 1991. Using the data from 1976-1986 periods, Kogut and Chang [11] also concluded that the real appreciation of the Japanese yen lead to more entries of Japanese firms into the U.S. Blonigen [9] who reported that the real exchange rate between the Japanese yen and the US dollar had a positive relationship with the number of Japanese acquisitions (proxy for FDI) in the US, especially in the manufacturing industries with more firm-specific assets, supporting Kogut and Chang's [11] findings.

Baek and Okawa [29] found that a depreciation of the Asian currencies against the dollar significantly increases FDI in the export-oriented leading sectors such as chemical and electrical machinery sectors. Particularly, Japanese FDI in the electrical machinery is the most export-oriented sector where over 70 percent of the total sales in this industry by the Japanese subsidiaries in Asia were for exports in 1997 and 1998. The results suggested that a depreciation 
of Asian currencies against the dollar made the products in the export-oriented electrical machinery sector more competitive in international trade and thus increased the FDI in those countries as the production site for exports. Liu's [12] study on the FDI inflows to China from 18 major source countries during 1989-2006 also indicated a positive relationship between exchange rate and FDI. In fact, the study also found out that most of the MNEs from Hong Kong and Taiwan have made investments in China in order to acquire cheaper labour costs. Nevertheless, the study by Farrell et al. [4] for eight manufacturing industries in 15 countries showed mixed empirical evidence. Using panel data analysis, they found out the negative but insignificant effect of exchange rate on the FDI, though the result was somewhat sensitive to country inclusion.

With the financial account liberalizations in the last two decades, there is an opportunity to investigate the impact of foreign exchange on emerging markets [20,30]. Dees [16] found that the effect of real exchange rate was negative. The empirical findings indicated that the decrease in China's real exchange rate was associated with the increase in the stock of FDI. It implied that a depreciation of the real value of the Chinese currency encouraged the growth of the inward FDI. However, Ali and Guo's [31] survey results showed that the exchange rate was not the main factor for the MNE to take advantage of the foreign opportunities in China. Meanwhile, using data from 18 source countries during the period of 1989-2006, Liu [12] found that depreciation of real exchange rate had a positive relationship with the FDI inflows into China. Vijayakumar et al. [32] also showed a significant negative relationship between FDI and the real exchange rate using yearly observations for the period of 1975-2007 for five fast developing countries, namely, Brazil, Russia, India, China, and South Africa. Osinubi and Amaghionyeodiwe's [13] study findings revealed a significant positive relationship between real inward FDI and exchange rate in Nigeria. This implied thata depreciation of the naira increases real inward FDI.

Meanwhile, Chong and Tan's [33] findings indicated the long-run comovement between exchange rate and FDI. Ang's [3] study supported the proposition that currency value depreciation is associated with greater FDI inflows. This is because a diminished currency value would lead to a higher relative wealth position of foreign investors and thus lower the relative cost of capital. This allows foreign investors to make a significantly larger investment in terms of the domestic currency. Wafure and Nurudeen's [14] study revealed that exchange rate depreciation is one of the main determinants of foreign direct investment in Nigeria. Xing's [34] study indicated that the devaluation of the yuan (renminbi) improved China's competitiveness in attracting FDI from Japan, and the response of FDI to the change of the real exchange rate was elastic.

Study by Thomas and Grosse [35] on the inward FDI to Mexico during the period of 1980-1995 also showed that firms from a country with a higher real exchange rate were more likely to invest in Mexico. This indicated that FDI is viewed as a foreign exchange rate exposure hedging tool because the MNEs based in the home country would find it difficult to export as domestic goods become less competitive [36]. However, there are two important things to be considered in this case. Firstly, the exchange rate must be the real exchange rate because the rate represents competitiveness and economic exposure. Secondly, the relationship between FDI and exchange rate cannot be simultaneous since it would take time between the decision to make investment and the exchange rate change, unless the decision is based on a shortterm decision through expectation. Love and Lage-Hildago's [37] study on the investment flows from USA to Mexico between 1967 and 1994 indicated that the exchange rate had an effect on the timing of the investment decision when using the short-run dynamic model. Meanwhile, Pan's [38] study that examined the impacts of source and host country factors, including the exchange rate on the inflow of FDI into China between 1984 and 1996, showed a negative but insignificant relationship. The findings implied the FDI in the emerging markets may be for long-term decision because the MNEs may not take out their profits in the short-term duration.

In conclusion, even though the FDI exchange rate hypothesis has been intensively studied since the creation of the theory, there are still mixed empirical supports. This controversy motivates this research on the comparative relationship between the exchange rate and FDI inflows in Malaysia, Singapore, the Philippines, and Thailand, where the empirical evidence is still not thoroughly developed.

\section{Data and Methodology}

The ASEAN region is not only one of the most dynamic economic regions in the world but also interrelated and most attractive investment locations for MNEs [39]. Amongst the ASEAN countries, Singapore is an example of how a successful host country can harness FDI as well as MNEs in order to achieve its objectives towards industrial development and sustainable economic growth. The FDI uniqueness of the ASEAN countries may range from tight investment policies (more restrictive investment policies) to rather liberal investment policies (less restrictive investment policies). The annual data set in this study consists of FDI and exchange rate for the period of 1971-2011 which were obtained from several sources. The FDI inflows were obtained from the United Nations Conference on Trade and Development (UNCTAD) FDI database, while the exchange rate and other related variables for respective countries were collected from World Development Indicators and Global Development Finance databases. FDI inflows consist of capital provided (either directly or through other related enterprises) by foreign direct investors to FDI enterprise or capital received by foreign direct investors from FDI enterprise [22]. There are only four of the ASEAN countries (Malaysia, the Philippines, Singapore, and Thailand) that had a complete set of information for the period of 1971-2011.

The FDI inflows are then adjusted by dividing the nominal FDI value at current US dollars prices by the GDP at a constant price (base year $=2000$ ) for controlling the country 
size $[20,40]$. The simple calculation of the adjusted FDI (AFDI) can be shown as follows:

$$
\mathrm{AFDI}=\frac{\mathrm{FDI}_{\text {Current Price }}}{\mathrm{GDP}_{2000}} .
$$

The nominal exchange rate (NER) is the domestic currency vis-à-vis the foreign currency, which is the U.S. dollar. Choosing the right real exchange rate index has been debated in the literature whether to choose individual or multicurrency index because the selection of the index is not determined by the theory or model used [41]. Using individual currency is suitable if the countries have high exposure to a particular currency through international business [25]. The movement of the U.S dollar has a significant effect on most ASEAN countries in international trade, FDI, and policy making during crisis. Therefore, for the purpose of the study, we calculate the real exchange rate indices of the respective currency against the U.S dollar by using the purchasing power parity (PPP) approach. By adjusting real exchange rates for inflation, we can get a more correct PPP deviation measurement because the inflation in the emerging markets is comparatively larger and more unstable than in the developed economies $[25,42]$.

The study define the real exchange rate (RER) as the NER of the domestic currency vis-à-vis the U.S dollar multiplied by the ratio of the price level in the USA to the price levels in the domestic currency. In other words, the NER is adjusted for the price differential by keeping the US prices $\left(P_{\mathrm{US}}\right)$ in the numerator and the domestic price $\left(P_{H}\right)$ in the denominator. The US price level is proxies by the Wholesale Price Index (WPI) of the USA, while the Consumer Price Index (CPI) is used as a proxy for the domestic price level. Thus, a rise (fall) in the real exchange rate index indicates a real depreciation (real appreciation) of the local currency. The study follows Osinubi and Amaghionyeodiwe [13] in calculating the RER in a simple form as follows:

$$
\mathrm{RER}=\mathrm{NER} \times \frac{P_{\mathrm{US}}}{P_{H}}=\mathrm{NER} \times \frac{\mathrm{WPI}}{\mathrm{CPI}} .
$$

While the regression technique is acceptable in analyses with cross-country data, it is not quite appropriate to the time-series data from a single country $[43,44]$. Thus, one should be cautious in determining whether the variables used in the regressions are stationary and whether the level or the change effects are more appropriate for analysis. Therefore, the appropriate nature of the relation between FDI and exchange rates in the long-run and short-run can be sorted out empirically by time series methods such as cointegration analysis and error correction model.

For this study, the construction of the exchange rate and FDI relationships is similar to studies done by Osinubi and Amaghionyeodiwe [13] and Yol and Teng [43]. In this study, the approach used in estimating the relationship between exchange rate and FDI is based on the econometric modelling of ARDL bounds testing approach to cointegration and Error Correction Model (ECM) based ARDL for causality tests. The theory of cointegration arises out of the need to integrate short-run dynamics with long-run equilibrium. In cases where the data series exhibits the presence of unit roots, short-run dynamic properties of the model can only be captured in an error correct model when the existence of cointegration has been demonstrated. If the variables (exchange rate and FDI) are found to be cointegrated, then there must be an existence of associated error-correction mechanism, according to Engle and Granger [45].

As a norm, unit root tests will be conducted to check for stationarity and the order of integration of the series variables before carrying out the cointegration test. In this case, this study conducts unit root tests by adopting the Dickey-Fuller, DF, or Augmented Dickey-Fuller, ADF [46], and PhillipsPerron, PP [47], as well as the Dickey-Fuller-Generalized Least Square, DF-GLS [48].

This study then employs the Autoregressive Distributed Lag (ARDL) bounds testing approach for cointegration by Pesaran et al. [49] to check for the long-run movement of the variables as well as to consider the robustness of the results. The ARDL bounds testing approach is given as follows:

$$
\Delta y_{t}=\alpha_{0}+\alpha_{1} y_{t-1}+\alpha_{2} x_{t-1}+\sum_{i=1}^{m} \beta_{i} \Delta y_{t-i}+\sum_{j=0}^{n} \gamma_{j} \Delta x_{t-j}+\varepsilon_{t},
$$

where $\alpha_{0}$ is the drift component and $\varepsilon_{t}$ are white noise errors. Following Pesaran et al. [49], two separate statistics are employed to "bounds test" for the existence of a longrun relationship: an $F$-test for the joint significance of the coefficients of the lagged levels in (3) (so that $H_{0}: \alpha_{1}=$ $\alpha_{2}=0$ ) and a $t$-test for the null hypothesis $H_{0}: \alpha_{1}=0$ (see also [50]). However, only the $F$-statistics will be used in this study. Two asymptotic critical value bounds provide a test for cointegration when the independent variables are $I(d)$ (where $0 \leq d \leq 1$ ): a lower value assuming the regressors are $I(0)$ and an upper value assuming purely $I(1)$ regressors. If the test statistics exceed their respective upper critical values, we can conclude that a long-run relationship exists. If the test statistics fall below the lower critical values, we cannot reject the null hypothesis of no cointegration. If the statistics fall within their respective bounds, the inference would be inconclusive.

In addition, for long-run relations analysis, we consider the finite-order of ARDL $(1,0)$ model [51] with slight modification as follows:

$$
y_{t}=\alpha_{0}+\alpha_{1} y_{t-1}+\alpha_{2} x_{t}+\varepsilon_{t}
$$

or in more general form of conditional ARDL $(p, q)$ model as follows:

$$
y_{t}=\alpha_{0}+\sum_{i=1}^{p} \alpha_{1 i} y_{t-i}+\sum_{i=0}^{q} \alpha_{2 i} x_{t-i}+\varepsilon_{t} .
$$

The causal relationship issue in this study is tested by using Error Correction Model based on ARDL (ECMARDL). Generally, in the case where $y_{t}$ and $x_{t}$ are stationary variables $I(0),(6)$ and (7) without the error correction term can be estimated using the least squares method in level form. However, if $y_{t}$ and $x_{t}$ are nonstationary variables I(1) and 
TABLE 1: Unit root test.

\begin{tabular}{|c|c|c|c|c|c|c|c|}
\hline \multirow{3}{*}{ Country } & \multirow{3}{*}{ Variable } & \multicolumn{6}{|c|}{ Test type } \\
\hline & & \multicolumn{2}{|r|}{$\mathrm{ADF}$} & \multicolumn{2}{|r|}{ PP } & \multicolumn{2}{|r|}{ DF-GLS } \\
\hline & & Intercept & Intercept and trend & Intercept & Intercept and trend & Intercept & Intercept and trend \\
\hline \multirow{2}{*}{ Malaysia } & AFDI & $I(0)$ & $I(1)$ & $I(0)$ & $I(1)$ & $I(0)$ & $I(1)$ \\
\hline & RER & $I(1)$ & $I(1)$ & $I(1)$ & $I(0)$ & $I(1)$ & $I(1)$ \\
\hline \multirow{2}{*}{ The Philippines } & AFDI & $I(0)$ & $I(0)$ & $I(0)$ & $I(0)$ & $I(0)$ & $I(0)$ \\
\hline & RER & $I(1)$ & $I(1)$ & $I(1)$ & $I(1)$ & $I(0)$ & $I(1)$ \\
\hline \multirow{2}{*}{ Thailand } & AFDI & $I(1)$ & $I(0)$ & $I(1)$ & $I(0)$ & $I(1)$ & $I(0)$ \\
\hline & RER & $I(1)$ & $I(1)$ & $I(1)$ & $I(1)$ & $I(0)$ & $I(1)$ \\
\hline \multirow{2}{*}{ Singapore } & AFDI & $I(1)$ & $I(0)$ & $I(1)$ & $I(0)$ & $I(1)$ & $I(0)$ \\
\hline & RER & $I(1)$ & $I(1)$ & $I(1)$ & $I(1)$ & $I(1)$ & $I(1)$ \\
\hline
\end{tabular}

Notes: $I(0)$ and $I(1)$ indicate stationary at level and first difference, respectively. All variables are transformed into logarithms $(L)$.

TABLE 2: ARDL bounds test.

\begin{tabular}{|c|c|c|c|}
\hline Country & Equation: $\operatorname{ARDL}(p, q)$ & $F$-Statistic & Diagnostic test \\
\hline Malaysia & $\operatorname{ARDL}(0,3): F(\operatorname{AFDI} \mid \mathrm{RER})$ & $5.5317^{* *}$ & $\begin{array}{l}\chi_{\mathrm{SC}}^{2}=0.0108 \\
\chi_{\text {Het }}^{2}=0.0015\end{array}$ \\
\hline The Philippines & $\operatorname{ARDL}(0,0): F(\mathrm{AFDI} \mid \mathrm{RER})$ & $4.3418^{*}$ & $\begin{array}{c}\chi_{\mathrm{SC}}^{2}=1.4191 \\
\chi_{\mathrm{Het}}^{2}=0.05672\end{array}$ \\
\hline Thailand & $\operatorname{ARDL}(0,0): F(\mathrm{AFDI} \mid \mathrm{RER})$ & 0.7247 & $\begin{array}{l}\chi_{\mathrm{SC}}^{2}=0.0421 \\
\chi_{\text {Het }}^{2}=1.9710\end{array}$ \\
\hline Singapore & $\operatorname{ARDL}(0,0): F(\operatorname{AFDI} \mid \mathrm{RER})$ & $4.3578^{*}$ & $\begin{array}{l}\chi_{\mathrm{SC}}^{2}=0.1853 \\
\chi_{\mathrm{Het}}^{2}=0.0133\end{array}$ \\
\hline
\end{tabular}

Notes: ${ }^{* * *},{ }^{* *}$, and ${ }^{*}$ denote significant and rejected at the $1 \%, 5 \%$, and $10 \%$ levels, respectively. Figures in ( ) indicate numbers of lag structures selected based on the lowest SIC. The models were estimated using Microfit 4.1. All variables are transformed into logarithms $(L)$.

TABLE 3: Long-run coefficients based ARDL models.

\begin{tabular}{lc}
\hline Regressor & Coefficient \\
\hline Malaysia: ARDL $(1,0)$ based SIC & \\
Dependent variable: AFDI $t$ & \\
$\alpha_{0}$ & -2.8129 \\
& {$[1.5779]$} \\
RER $_{t}$ & -0.4129 \\
& {$[1.4256]$}
\end{tabular}

The Philippines: ARDL(1, 0) based SIC

Dependent variable: AFDI $_{t}$

$\begin{array}{lc}\alpha_{0} & 2.6590 \\ & {[11.0745]} \\ \text { RER }_{t} & -1.9198 \\ & {[2.8879]} \\ \text { Singapore: ARDL }(1,0) \text { based SIC } & \\ \alpha_{0} & -0.7291 \\ \text { RER }_{t} & {[0.7340]} \\ \end{array}$

Notes: Figures in ( ) and [] indicate numbers of lag structures selected based on the lowest SIC and the estimated standard errors. The models were estimated using Microfit 4.1. All variables are transformed into logarithms $(L)$. do not cointegrate, the ECM such as (6) and (7) without the error correction term in the first difference form can be used, whereas (6) and (7) in ECM-ARDL framework exactly can be used in the case where $y_{t}$ and $x_{t}$ are $I(1)$ and cointegrated. We have

$$
\begin{aligned}
& \Delta y_{t}=\alpha_{0}+\sum_{i=1}^{m} \alpha_{1 i} \Delta y_{t-i}+\sum_{j=0}^{n} \alpha_{2 j} \Delta x_{t-j}+\alpha_{3} \varepsilon_{t-1}+u_{t}, \\
& \Delta x_{t}=\beta_{0}+\sum_{i=1}^{k} \beta_{1 i} \Delta x_{t-i}+\sum_{j=0}^{l} \beta_{2 j} \Delta y_{t-j}+\beta_{3} \varepsilon_{t-1}+v_{t},
\end{aligned}
$$

where $\varepsilon_{t-1}$ is an error correction term obtained from cointegration tests and $x_{t}$ is Granger cause to $y_{t}$ if all $a_{2 j}$ in (6) is significant without taking into account $\beta_{2 j}$. On the other hand, $y_{t}$ would Granger cause to $x_{t}$ if all $\beta_{2 j}$ in (7) is significant without taking into account $a_{2 j}$. Bilateral causal relationship exists between $y_{t}$ and $x_{t}$ if all $\alpha_{2 j}$ and $\beta_{2 j}$ are significant. Coefficients $\alpha_{3}$ and $\beta_{3}$ are referred to as error correction coefficients because both coefficients show a number of variables in $y_{t}$ and $x_{t}$ reacting to the cointegration error which is $y_{t-1}-\alpha_{0}-\alpha_{1} x_{t-1}=\varepsilon_{t-1}$ or $y_{t-1}-\beta_{0}-\beta_{1} x_{t-1}=$ $\varepsilon_{t-1}$. The rationale is that such error will lead to the correction caused by conditions imposed upon $\alpha_{3}$ and $\beta_{3}$ to ensure that the stability conditions are fulfilled. These coefficients $\left(\alpha_{3}\right.$ and $\beta_{3}$ ) are also referred to as adjustment speed coefficients, as well as long-run causality coefficients. 

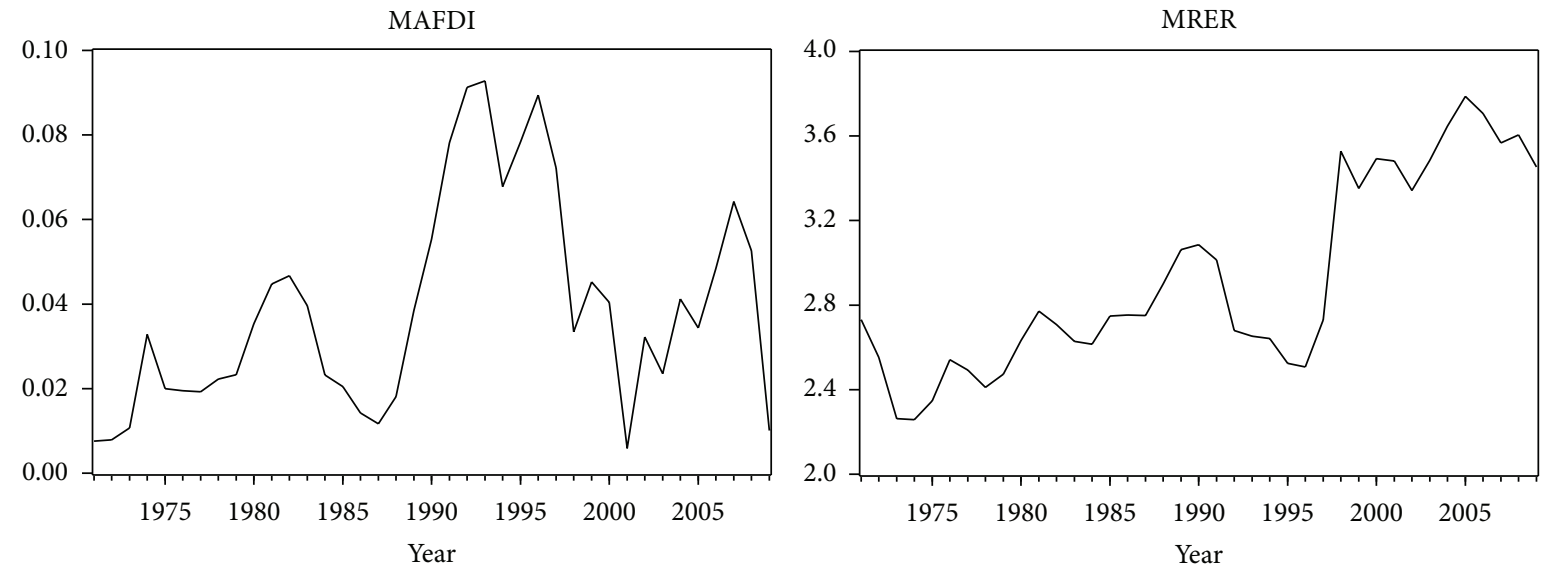

FIgURe 1: Malaysia-FDI and RER.
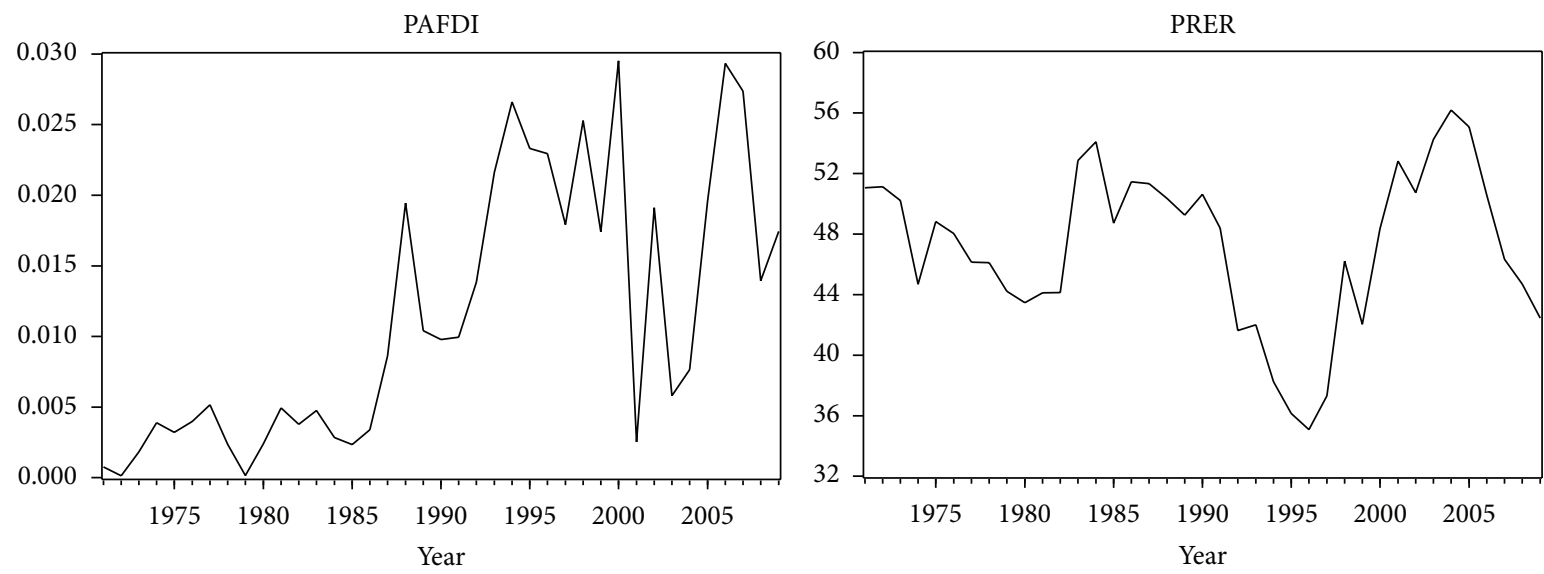

FIgure 2: The Philippines-FDI and RER.

\section{Empirical Results}

The original series of the exchange rate movement and FDI relationship for respective ASEAN-4 countries is shown in Figures 1, 2, 3, and 4. In general, both series variables in all countries fluctuated over the periods. Unit root test results using $\mathrm{ADF}, \mathrm{PP}$, and DF-GLS show that all variable series of all cases (Malaysia, the Philippines, Thailand, and Singapore) produced mixed results but up to $I(1)$ only. These results suggest that most of the variable series have different integration order (see Table 1).

Since the unit root tests indicated that most of the series variables have a different order of integration, more robust cointegration analysis is then tested using the ARDL bounds testing approach. The results showed that there are long-run cointegration relationships between FDI and exchange rate in the case of Malaysia, the Philippines, and Singapore, but none in Thailand. These proposed that both FDI and exchange rate for the said countries may tend to move together towards equilibrium (see Table 2). Noted, however, that the focus of this study is FDI as the dependent variable and not the other way around. Meanwhile, the associated estimated longrun coefficients based on ARDL models between FDI and exchange rate are shown in Table 3 . The results show that all the coefficients have the correct sign as expected.

Dynamic interaction or short-run causal relationship as well as long-run causality analysis is then tested using the ECM-ARDL as shown in Table 4. The results reveal that both Singapore and the Philippines show long-run bidirectional causality between exchange rate and FDI (see Table 4), whereas long-run unidirectional causality running from the exchange rate to the FDI exists in Malaysia. Furthermore, the result also shows the existence of short-run unidirectional causality running from the exchange rate to the FDI in Singapore. However, there is no evidence of short-run causality in the Philippines and Malaysia.

The error correction coefficients as shown in Table 4 are significant for all countries, especially in the case of the Philippines and Singapore. The estimated error correction coefficients for the Philippines and Singapore have the correct sign and suggest from low to moderate speed of convergence to equilibrium, which is about $21 \%$ to $44 \%$ (the Philippines) 
TAFDI

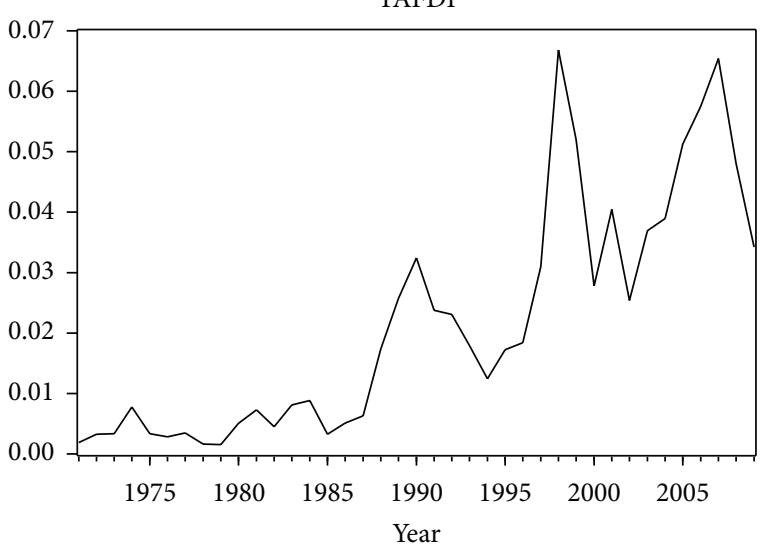

TRER

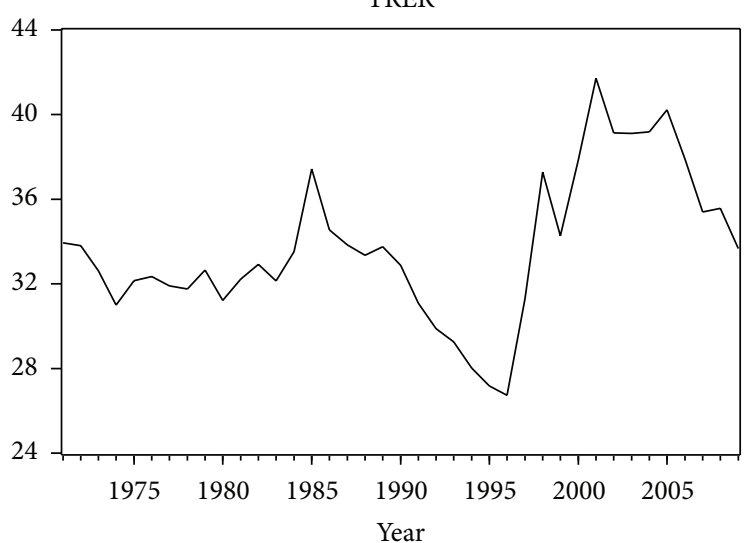

FIgURE 3: Thailand-FDI and RER.
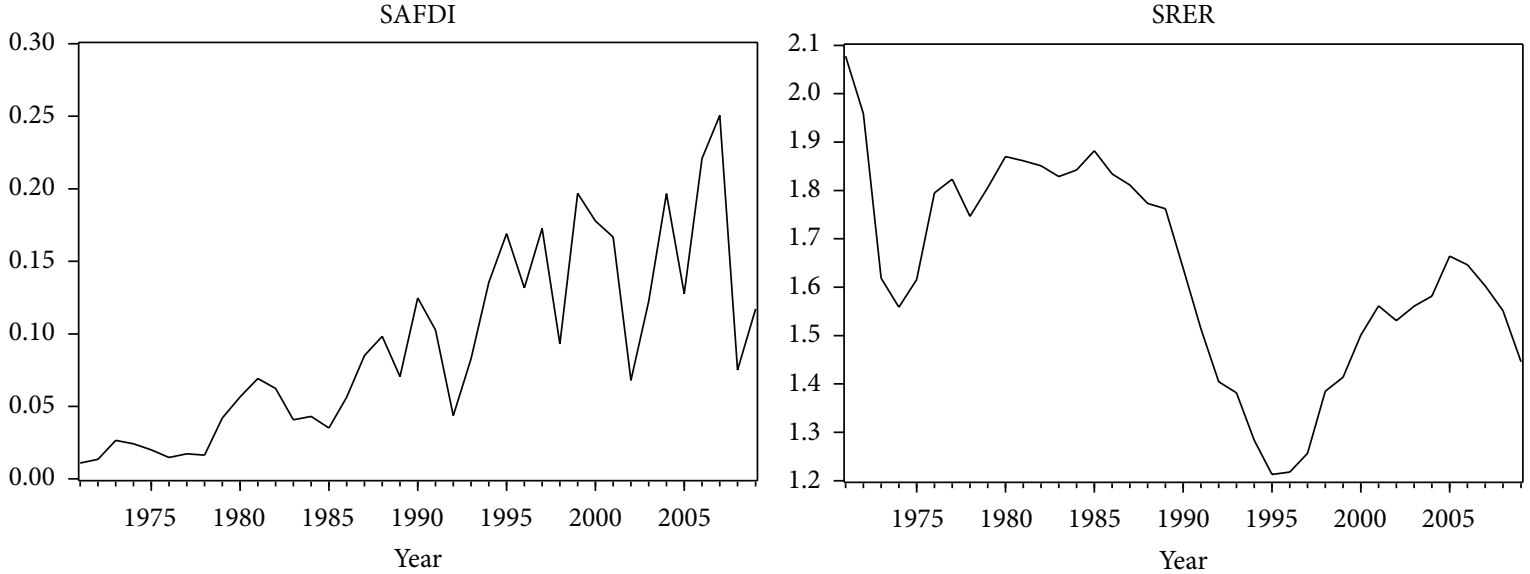

FIGURE 4: Singapore-FDI and RER.

TABLE 4: ECM based ARDL.

\begin{tabular}{|c|c|c|c|c|c|}
\hline Country & $\operatorname{ARDL}(p, q)$ & Null hypothesis: $H_{0}$ & Wald statistic, $\chi^{2}$ & ECT & Diagnostic test \\
\hline \multirow[b]{2}{*}{ Malaysia } & $\operatorname{ARDL}(1,0)$ & $\mathrm{RER}=/>$ AFDI & 0.0840 & $-0.5161^{* * *}$ & $\chi_{\mathrm{SC}}^{2}=0.4264$ \\
\hline & $\operatorname{ARDL}(1,0)$ & $\mathrm{AFDI}=/>\mathrm{RER}$ & 0.6316 & -0.0976 & $\begin{aligned} \chi_{\mathrm{Het}}^{2} & =0.4337 \\
\chi_{\mathrm{SC}}^{2} & =1.1965 \\
\chi_{\mathrm{Het}}^{2} & =0.5310\end{aligned}$ \\
\hline \multirow[t]{2}{*}{ The Philippines } & $\operatorname{ARDL}(1,0)$ & $\mathrm{RER}=/>$ AFDI & 0.4160 & $-0.4358^{* * *}$ & $\begin{array}{l}\chi_{\mathrm{SC}}^{2}=1.7151 \\
\chi_{\mathrm{Het}}^{2}=1.5380\end{array}$ \\
\hline & $\operatorname{ARDL}(1,0)$ & $\mathrm{AFDI}=/>\mathrm{RER}$ & 0.5771 & $-0.2088^{*}$ & $\begin{array}{l}\chi_{\mathrm{SC}}^{2}=0.6132 \\
\chi_{\mathrm{Het}}^{2}=3.0729\end{array}$ \\
\hline \multirow{2}{*}{ Singapore } & $\operatorname{ARDL}(1,0)$ & $\mathrm{RER}=/>$ AFDI & $3.0906^{*}$ & $-0.3838^{* * *}$ & $\begin{array}{l}\chi_{\mathrm{SC}}^{2}=0.1754 \\
\chi_{\mathrm{Het}}^{2}=1.2630\end{array}$ \\
\hline & $\operatorname{ARDL}(2,0)$ & $\mathrm{AFDI}=/>\mathrm{RER}$ & 0.5728 & $-0.0996^{*}$ & $\begin{array}{l}\chi_{\mathrm{SC}}^{2}=0.0485 \\
\chi_{\mathrm{Het}}^{2}=1.4262\end{array}$ \\
\hline
\end{tabular}

Notes: $^{* * *},{ }^{* *}$, and ${ }^{*}$ denote significant and rejected at the $1 \%, 5 \%$, and $10 \%$ levels, respectively. $=/>$ indicates "does not Granger cause" and ECT is error correction coefficient. Figures in ( ) indicate numbers of lag structures selected based on the lowest SIC. The models were estimated using Microfit 4.1. All variables are transformed into logarithms $(L)$. 
and $10 \%$ to $38 \%$ (Singapore), respectively. Meanwhile, the estimated error correction coefficient for Malaysia also has the correct sign with at low to moderate speed of convergence, which is about $10 \%$ to $52 \%$. These scenarios imply that the long-run disequilibrium is corrected every year for about $21 \%$ to $44 \%$ in the Philippines, $10 \%$ to $38 \%$ in Singapore, and $10 \%$ to $52 \%$ in Malaysia.

\section{Discussion and Conclusion}

This paper enhances the understanding of the real effects of exchange rates in ASEAN markets. The researchers have argued that the effects of the real exchange appreciation of the host country on the FDI inflows can be in two directions depending on the objective of the FDI and cost reduction. In conjunction to the host country currency appreciation, the FDI inflows become positive if the FDI objective is to serve the local market, but the relationship becomes negative if the FDI objective is to reexport or reduce cost purpose.

Thus, this study has tested the long-run cointegration relationship and the direction of the causal relations between FDI and exchange rate in Malaysia, the Philippines, Singapore, and Thailand. The empirical findings based on the ARDL bounds test suggest that there is evidence of long-run cointegration relationships between FDI and exchange rate for the case of Malaysia, Singapore, and the Philippines with all countries (except Thailand) recording negative coefficient. As this study refers the foreign exchange rate as the number of home currency units per foreign currency, the negative relationship implies that the appreciation (a fall in the exchange rate indices) of the local currency has a positive impact on FDI inflows. Contrary to the previous studies in developing countries (e.g., $[12,13,29,32])$ that indicated a significant relationship between FDI and exchange rate, the current study shows the insignificant long-run relationship in Thailand except for the Philippines and Malaysia.

Meanwhile, by using ECM based on the ARDL approach for causality test, both Singapore and the Philippines show long-run bidirectional causality between exchange rate and FDI. Furthermore, long-run unidirectional causality running from the exchange rate to FDI exists in Malaysia, while shortrun unidirectional running from the exchange rate to FDI exists in Singapore.

The empirical findings suggest that there is evidence of country effect on the exchange rate and FDI relationship as indicated in Farrell et al. [4]. Although the study showed that the exchange rate can be the determinant of FDI inflows (for the case of Singapore, Malaysia, and the Philippines), it is insignificant in the case of Thailand. These findings suggest that the importance of the exchange rate to attract FDI inflows is still questionable as it may provide different effect and direction across countries. Nevertheless, the evidence of insignificant of the relationship in this current study (e.g., Thailand) does not suggest the unimportant effect of exchange rate to the FDI inflows completely. These results actually provide more opportunities for the researchers to study the reasons behind the insignificant relationship. The current study applies aggregate FDI, whereas there is a possibility of relationship of exchange rate and FDI flows in different types of economic sectors. At the aggregate level, it does not consider the effect of exchange rate on each of the economic sectors. Each sector may have different reactions towards the exchange rate movement which may provide different relationship directions. Meanwhile, the true value of the respective country currency is also questionable due to the government intervention in managing the foreign exchange rate which may affect the relationship between the exchange rate and FDI.

Therefore, for future research, the study proposes the breakdown of the investment inflows in order to see the different effect of exchange rate on the economic sectors. Besides, since the investment decision making seems to be in the long-run, the study also proposes the inclusion of exchange rate movements via systematic exchange rate (monetary) policy to promote an attractive long-term FDI for a country in order to achieve sustainable economic development.

\section{Conflict of Interests}

The authors declare that there is no conflict of interests regarding the publication of this paper.

\section{References}

[1] J. W. Cho, "Foreign direct investment: determinants, trends in flows and promotion policies," in Investment Promotion and Enterprise Development Bulletin for Asia and the Pacific, K. Lakshminarayanan, Ed., no.1, pp. 99-112, ESCAP Works Towards Reducing Poverty and Managing Globalization, United Nations, 2003, http://www.unescap.org/tid/publication/ indpub2259.pdf.

[2] I. A. Moosa, Foreign Direct Investment: Theory, Evidence and Practice, Palgrave, New York, NY, USA, 2002.

[3] J. B. Ang, "Determinants of foreign direct investment in Malaysia," Journal of Policy Modeling, vol. 30, no. 1, pp. 185-189, 2008.

[4] R. Farrell, N. Gaston, and J.-E. Sturm, “Determinants of Japan's foreign direct investment: an industry and country panel study, 1984-1998," Journal of the Japanese and International Economies, vol. 18, no. 2, pp. 161-182, 2004.

[5] M. Kogid, J. Lily, R. Asid, D. Mulok, and N. Loganathan, "Economic growth and foreign direct investment in Malaysia: evidence from empirical testing," International Journal Asian Business Economies, vol. 1, no. 1, pp. 1-13, 2011.

[6] B. S. Lee and B. S. Min, "Exchange rates and FDI strategies of multinational enterprises," Pacific Basin Finance Journal, vol. 19, no. 5, pp. 586-603, 2011.

[7] J. M. Luiz and H. Charalambous, "Factors influencing foreign direct investment of South African financial services firms in Sub-Saharan Africa," International Business Review, vol. 18, no. 3, pp. 305-317, 2009.

[8] D. Shapiro and S. Globerman, "Foreign investment policies and capital flows in Canada: a sectoral analysis," Journal of Business Research, vol. 56, no. 10, pp. 779-790, 2003.

[9] B. A. Blonigen, "Firm-specific assets and the link between exchange rates and foreign direct investment," The American Economic Review, vol. 87, no. 3, pp. 447-465, 1997. 
[10] K. Froot and J. Stein, "Exchange rates and foreign direct investment: an imperfect capital markets approach," Quarterly Journal of Economics, vol. 106, no. 4, pp. 1191-1217, 1991.

[11] B. Kogut and S. J. Chang, "Platform investments and volatile exchange rates: direct investment in the U.S. by Japanese electronic companies," Review of Economics and Statistics, vol. 78, no. 2, pp. 221-231, 1996.

[12] W. H. Liu, "Determinants of FDI inflows to China: an empirical analysis of source country characteristics," Paper Presented at Taipei International Conference on Growth, Trade and Dynamics, 2010.

[13] T. S. Osinubi and L. A. Amaghionyeodiwe, "Foreign direct investment and exchange rate volatility in Nigeria," International Journal of Applied Econometrics and Quantitative Studies, vol. 2, pp. 83-116, 2009.

[14] O. G. Wafure and A. Nurudeen, "Determinants of foreign direct investment in Nigeria: an empirical analysis," Global Journal of Human Social Science, vol. 10, no. 1, pp. 26-34, 2010.

[15] R. E. Caves, "Exchange rate movements and foreign direct investment in the united states," in The Internationalization of US Markets, D. Audretsch and M. Claudon, Eds., New York University Press, New York, NY, USA, 1989.

[16] S. Dees, "Foreign direct investment in China: determinants and effects," Economics of Planning, vol. 31, no. 2-3, pp. 175-194, 1998.

[17] J. L. Combes, T. Kinda, and P. Plane, "Capital flows, exchange rate flexibility, and the real exchange rate," Journal of Macroeconomics, vol. 34, no. 4, pp. 1034-1043, 2012.

[18] C. A. Ibarra, "Capital flows and real exchange rate appreciation in Mexico," World Development, vol. 39, no. 12, pp. 2080-2090, 2011.

[19] J. Jongwanich and A. Kohpaiboon, "Capital flows and real exchange rates in emerging Asian countries," Journal of Asian Economics, vol. 24, pp. 138-146, 2013.

[20] R. Albuquerque, N. Loayza, and L. Servén, "World market integration through the lens of foreign direct investors," Journal of International Economics, vol. 66, no. 2, pp. 267-295, 2005.

[21] S. Y. Chia, "ASEAN strategies on foreign direct investment and prospects for ASEAN-India investments," Journal of Asian Economics, vol. 7, no. 4, pp. 701-721, 1996.

[22] UNCTAD (2011), The World Investment Report, United Nations Conference on Trade and Development, New York, NY, USA and Geneva, Switzerland, http://unctad.org.

[23] A. N. Berdiev, Y. Kim, and C. P. Chang, "The political economy of exchange rate regimes in developed and developing countries," European Journal of Political Economy, vol. 28, no. 1, pp. 38-53, 2012.

[24] A. Kanas, "Real or monetary? The US/UK real exchange rate, 1921-2002," Journal of International Financial Markets, Institutions and Money, vol. 15, no. 1, pp. 21-38, 2005.

[25] C. H. Lin, "Exchange rate exposure in the Asian emerging markets," Journal of Multinational Financial Management, vol. 21, no. 4, pp. 224-238, 2011.

[26] J. J. Choi and B. N. Jeon, "Financial factors in foreign direct investments: a dynamic analysis of international data," Research in International Business and Finance, vol. 21, no. 1, pp. 1-18, 2007.

[27] C. C. Hsu, J. Y. Wu, and R. Yau, "Foreign direct investment and business cycle co-movements: The panel data evidence," Journal of Macroeconomics, vol. 33, no. 4, pp. 770-783, 2011.

[28] G. Stevens, "Exchange rates and foreign direct investment: a note," Journal of Policy Modeling, vol. 20, no. 3, pp. 393-340, 1998.
[29] I. M. Baek and T. Okawa, "Foreign exchange rates and Japanese foreign direct investment in Asia," Journal of Economics and Business, vol. 53, no. 1, pp. 69-84, 2001.

[30] M. D. Chinn, "The (partial) rehabilitation of interest rate parity in the floating rate era: Longer horizons, alternative expectations, and emerging markets," Journal of International Money and Finance, vol. 25, no. 1, pp. 7-21, 2006.

[31] S. Ali and W. Guo, "Determinants of FDI in China," Journal of Global Business and Technology, vol. 1, no. 2, pp. 21-33, 2005.

[32] N. Vijayakumar, P. Sridharan, and K. C. S. Rao, "Determinants of FDI in BRICS countries: a panel analysis," International Journal of Business Science and Applied Management, vol. 5, no. 3, pp. 1-13, 2010.

[33] L. L. Chong and H. B. Tan, "Exchange rate risk and macroeconomic fundamentals: evidence from four neighbouring southeast asian economies," International Research Journal of Finance and Economics, vol. 16, pp. 88-95, 2008.

[34] Y. Xing, "Why is China so attractive for FDI? The role of exchange rates," China Economic Review, vol. 17, no. 2, pp. 198209, 2006.

[35] D. E. Thomas and R. Grosse, "Country-of-origin determinants of foreign direct investment in an emerging market: the case of Mexico," Journal of International Management, vol. 7, no. 1, pp. 59-79, 2001.

[36] J. P. Agarwal, "Determinants of foreign direct investment: a survey," Weltwirtschaftliches Archiv, vol. 16, no. 4, pp. 739-773, 1980.

[37] J. H. Love and F. Lage-Hidalgo, "Analysing the determinants of US direct investment in Mexico," Applied Economics, vol. 32, no. 10, pp. 1259-1267, 2000.

[38] Y. Pan, "The inflow of foreign direct investment to China: the impact of country-specific factors," Journal of Business Research, vol. 56, no. 10, pp. 829-833, 2003.

[39] S. Takagi and Z. Shi, "Exchange rate movements and foreign direct investment (FDI): Japanese investment in Asia, 19872008," Japan and the World Economy, vol. 23, no. 4, pp. 265-272, 2011.

[40] L. Alfaro, A. Chanda, S. Kalemli-Ozcan, and S. Sayek, "FDI and economic growth: the role of local financial markets," Journal of International Economics, vol. 64, no. 1, pp. 89-112, 2004.

[41] R. Aggarwal and J. T. Harper, "Foreign exchange exposure of "domestic" corporations," Journal of International Money and Finance, vol. 29, no. 8, pp. 1619-1636, 2010.

[42] J. Aizenman, M. Hutchison, and I. Noy, "Inflation targeting and real exchange rates in emerging markets," World Development, vol. 39, no. 5, pp. 712-724, 2011.

[43] M. A. Yol and N. Teng, "Estimating the domestic determinants of foreign direct investment flows in malaysia: evidence from cointegration and error-correction model," Jurnal Pengurusan, vol. 29, pp. 3-22, 2009.

[44] P. L. Tsai, "Determinants of foreign direct investment in Taiwan: an alternative approach with time-series data," World Development, vol. 19, no. 2-3, pp. 275-285, 1991.

[45] R. F. Engle and C. W. J. Granger, "Cointegration and error correction representation, estimation and testing," Econometrica, vol. 55, no. 2, pp. 251-276, 1987.

[46] D. A. Dickey and W. A. Fuller, "Distribution of the estimation for autoregressive time series with a unit root," Journal of the American Association, vol. 74, pp. 427-431, 1979.

[47] P. C. B. Phillips and P. Perron, "Testing for a unit root in time series regression,” Biometrika, vol. 75, no. 2, pp. 335-346, 1988. 
[48] G. Elliott, T. J. Rothenberg, and J. H. Stock, "Efficient tests for an autoregressive unit root," Econometrica, vol. 64, no. 4, pp. 813836, 1996.

[49] M. H. Pesaran, Y. Shin, and R. J. Smith, "Bounds testing approaches to the analysis of level relationships," Journal of Applied Econometrics, vol. 16, no. 3, pp. 289-326, 2001.

[50] A. Banerjee, J. J. Dolado, and R. Mestre, "Error-correction mechanism tests for cointegration in a single-equation framework," Journal of Time Series Analysis, vol. 19, no. 3, pp. 267-283, 1998.

[51] M. H. Pesaran and Y. Shin, "An autoregressive distributed lag modelling approach to cointegration analysis," in Econometrics and Economic theory in the 20th Century: The Ragnar Frisch Centennial Symposium, S. Strom, Ed., chapter 11, Cambridge University Press, Cambridge, UK, 1999. 

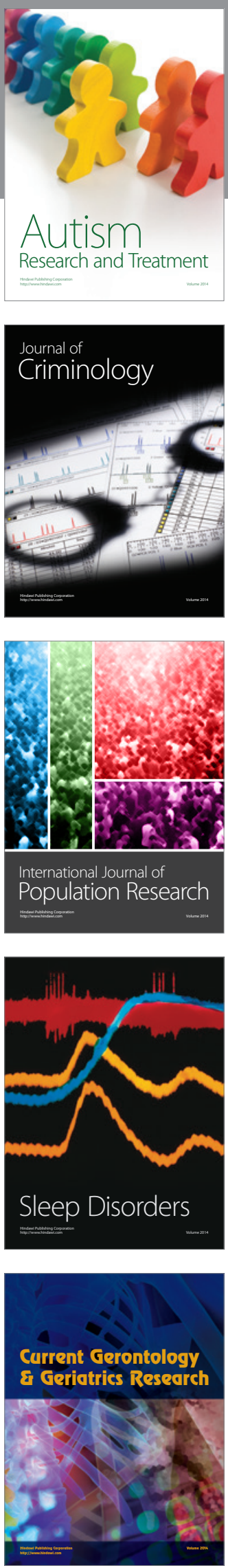
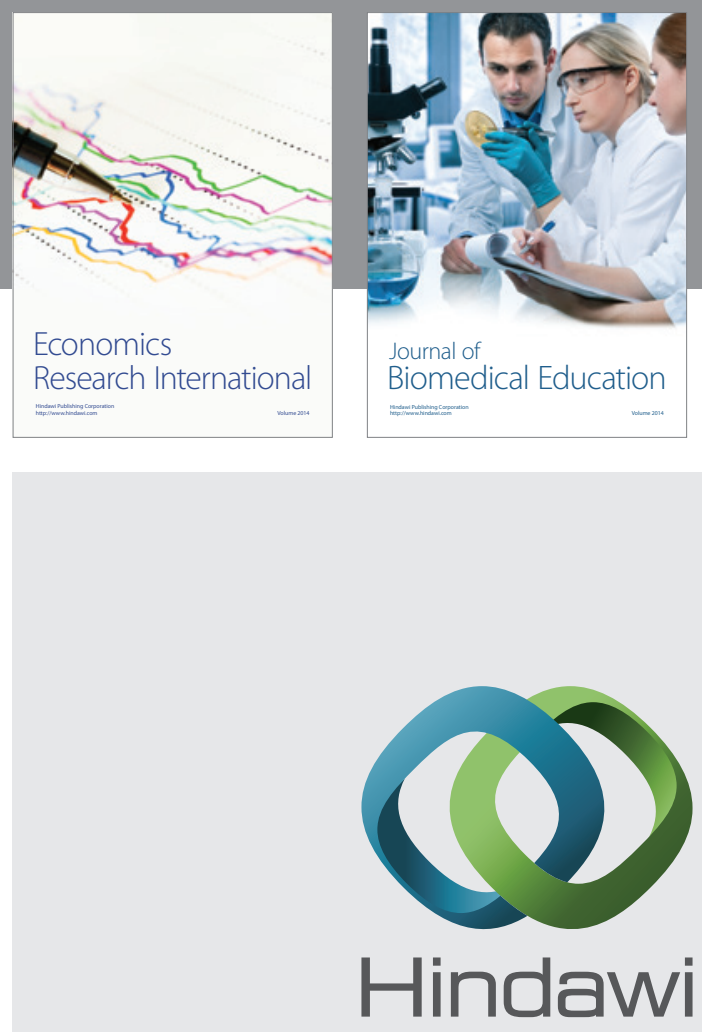

Submit your manuscripts at

http://www.hindawi.com
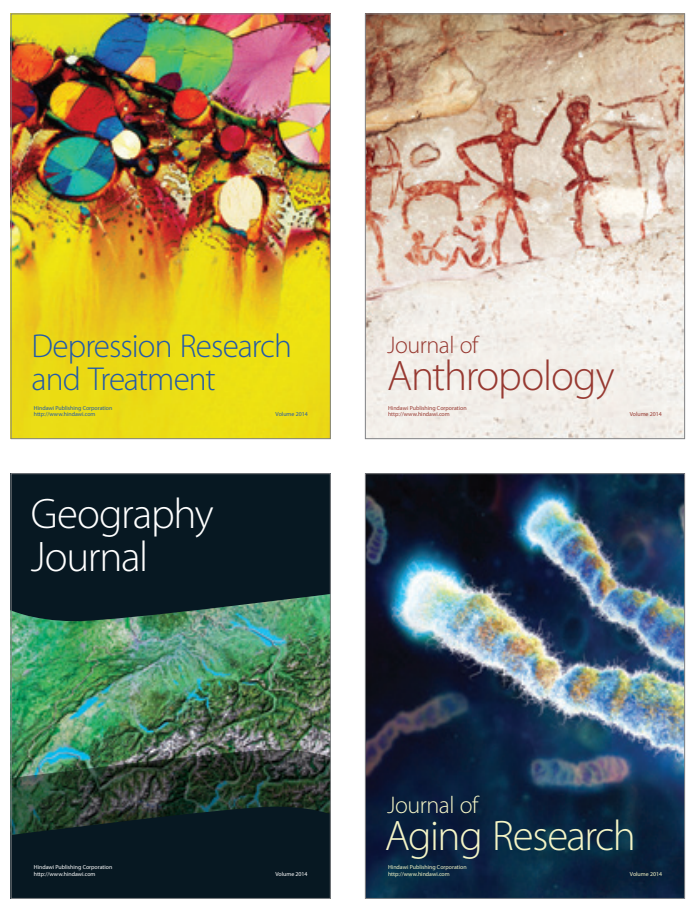
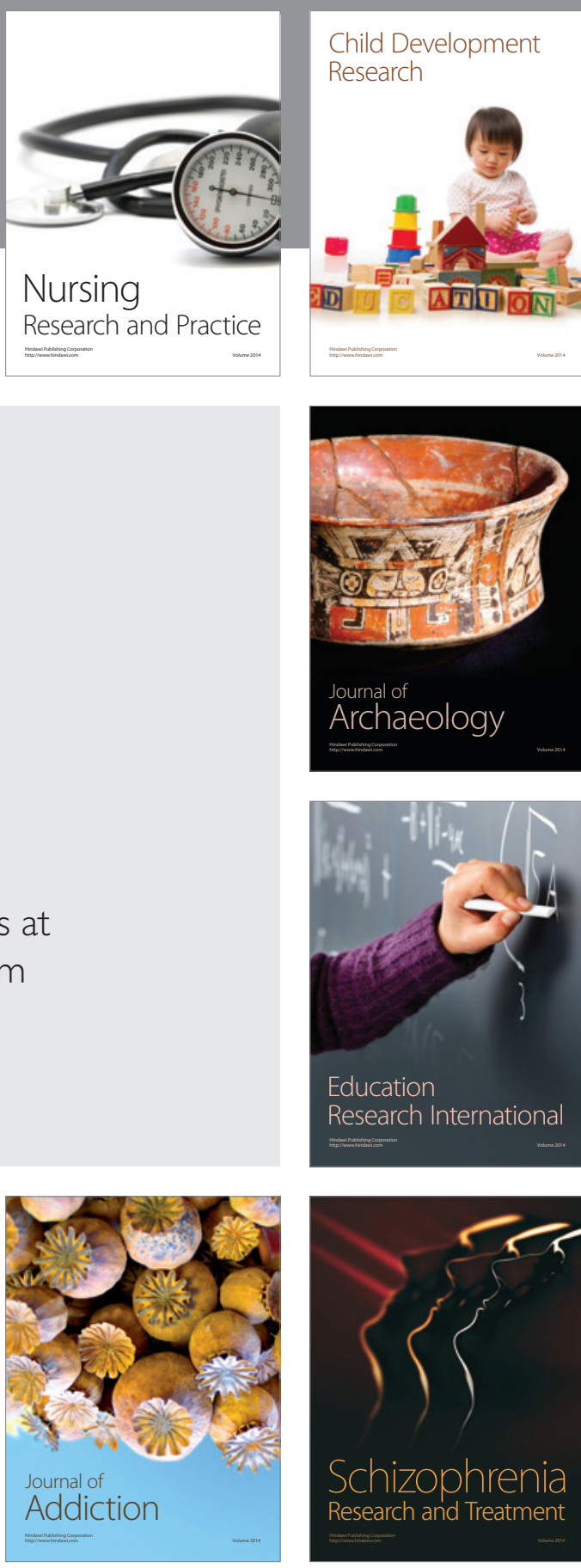

(D)
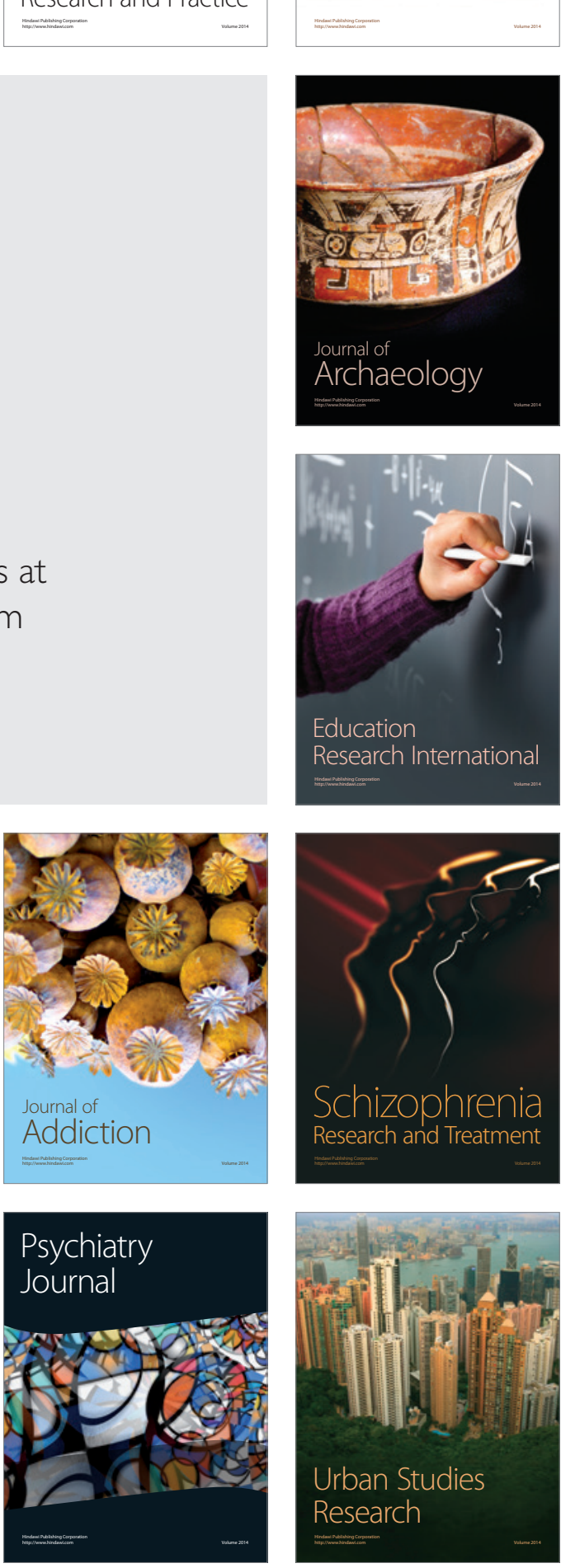